Sari Pediatri, Vol. 6, No. 4, Maret 2005: 172-175

\title{
Kejadian Luar Biasa Hepatitis A di SMPN-259 Jakarta Timur
}

\author{
Hanifah Oswari, Tuty Rahayu, Julfina Bisanto, Soedjatmiko
}

\begin{abstract}
Infeksi virus hepatitis A (VHA) ditularkan melalui transmisi fekal-oral, dan merupakan masalah di banyak negara, termasuk Indonesia. Bila terjadi pada anak usia sekolah akan mempengaruhi proses belajar dan membutuhkan pengeluaran biaya untuk perawatan. Tujuan penelitian ini untuk menentukan attact rate, penyebab, serta gejala penyakit pada Kejadian Luar Biasa (KLB) hepatitis akut di SMPN-259 Jakarta Timur. Penelitian ini bersifat prospektif observasional. Pada hasil penelitian didapatkan jumlah murid seluruhnya 1420 orang (usia 12-16 tahun), 1157 orang mengisi kuesioner yang dibagikan. Dari kuesioner didapatkan attack rate penyakit adalah 38,5 \% terdiri dari kelas I 165/ 442 (37,3 \%), kelas II 94/338 (27,8 \%), kelas III 187/377 (49,6\%). Murid yang memerlukan perawatan di rumah sakit 19/1157 (4,3\%). Tidak didapatkan murid yang meninggal (crude fatality rate $=0$ ). Pengambilan sampel dilakukan secara random pada kelompok murid yang sakit dengan hasil sebagai berikut: IgM anti HAV positif 38/45 $(84,4 \%)$ pada murid sakit yang tidak dirawat inap, dan $14 / 16(87,5 \%)$ pada murid sakit yang dirawat inap. Gejala klinis pada subyek dengan IgM anti HAV (+) meliputi urin gelap $67 \%$, lemah 57,7\%, demam $50 \%$, muntah $48 \%$, anoreksia $48 \%$, nyeri perut $46 \%$, kuning 36,5\%, diare $25 \%$, dan mialgia 19,2\%. Terdapat 51,6\% subyek dengan IgG antiHAV positif pada kelompok subyek yang tidak sakit. Kesimpulan attack rate KLB hepatitis akut di SMPN-259 Jakarta adalah 38,5 \% semua anak sembuh 0\%. Penyebab KLB hepatitis akut terbukti adalah VHA.
\end{abstract}

Kata kunci: hepatitis akut, hepatitis A, kejadian luar biasa (KLB), sekolah

থ irus hepatitis A (VHA) berasal dari genus RNA Hepatovirus, famili Picornavirus. VHA bersifat thermostabil, tahan asam, dan tahan terhadap lisis karena virus ini tidak mempunyai kapsul lipid. Sifat yang terakhir inilah yang menyebabkan virus ini efisien melakukan transmisi fekal-

\footnotetext{
Alamat korespondensi:

Dr. Hanifah Oswari, Sp.A

Departemen Ilmu Kesehatan Anak FKUI/RSCM

Jl. Salemba 6 Jakarta.

Telp/fax 021-3915712. Email: hanifah@idai.or.id
}

Hasil penelitian ini telah disampaikan dalam presentasi oral di Pertemuan Ilmiah Tahunan Ilmu Kesehatan Anak II IDAI, Batam, 12-14 Juli 2004 oral dari satu orang ke orang lain melalui makanan atau minuman yang terkontaminasi. ${ }^{1}$

Hepatitis A tidak dapat dibedakan dari hepatitis virus lainnya hanya berdasarkan gambaran klinis maupun epidemiologis. Pemeriksaan serologis IgM antiHAV dibutuhkan untuk konfirmasi diagnosis infeksi akut hepatitis A. IgG antiHAV yang timbul setelah infeksi dapat bertahan seumur hidup dan dapat memproteksi terhadap penyakit., ${ }^{2,3}$

Indonesia seperti juga negara-negara Asia Tenggara merupakan daerah endemis hepatitis A. ${ }^{4}$ Gejala klasik hepatitis virus A (HVA) umumnya timbul mendadak dengan gejala prodromal demam, nyeri kepala, malaise, kelelahan (fatique), dan gejala non spesifik gastrointestinal (mual, muntah, dan diare 
satu minggu setelah awitan), urin berwarna lebih gelap dan selanjutnya diikuti gejala kuning. ${ }^{1}$

Kejadian luar biasa (outbreak) hepatitis A pernah dilaporkan terjadi pada sekolah khusus, tempat penitipan anak, dan sekolah. - $^{-9}$ Pada laporan jaga di Departemen Ilmu Kesehatan Anak FKUI/RSCM pada tanggal 13 Oktober 2003 dilaporkan seorang anak dengan hepatitis akut dirawat. Pada anamnesis diketahui banyak teman-teman sekelas pasien yang secara bersamaan menderita penyakit yang sama. Pasien ini berasal dari SMPN 259 Kelurahan Bambu Apus Kecamatan Cipayung Kotamadya Jakarta Timur, Jakarta. Pada pemeriksaan selanjutnya diketahui pasien menderita HVA akut, terbukti dari hasil pemeriksaan IgM anti-HAV positif. Tujuan penelitian ini untuk mengetahui attack rate hepatitis akut ini, proporsi pasien yang memerlukan perawatan di rumah sakit, kematian yang terjadi (crude fatality rate), gejala klinis yang ditimbulkan, dan konfirmasi bahwa penyebab kejadian luar biasa ini memang disebabkan oleh virus hepatitis A. Penelitian ini merupakan bagian dari kerjasama dengan tim Subdit Survailans Departemen Kesehatan Republik Indonesia, tim Dinas Kesehatan Propinsi DKI Jakarta, tim Suku Dinas Kesehatan Kotamadya Jakarta timur, tim Puskesmas Cipayung, dan Kelompok Kerja (Pokja) hepatitis B.

\section{Metoda}

Penelitian ini adalah penelitian prospektif observasional. Subyek penelitian ini adalah seluruh populasi murid SMPN 259 Jakarta, Penelitian menggunakan metode kuesioner pada seluruh murid yang hadir pada saat kuesioner dibagikan untuk mendapatkan data pasien sakit dan gejala klinis yang timbul. Subyek dikelompokkan menjadi 3 kelompok yaitu kelompok kelas I,II, dan III. Untuk menentukan penyebab hepatitis virus, dilakukan dengan pemeriksaan IgM anti HAV pada seluruh pasien yang masih atau telah dirawat di rumah sakit dan $10 \%$ subyek (secara random) yang diketahui sakit tetapi tidak dirawat di rumah sakit. Penelitian ini dilakukan dari tanggal 13 sampai dengan 30 Oktober 2003.

\section{Hasil penelitian}

Pada data sekolah tercatat jumlah murid seluruhnya adalah 1420 orang, berusia antara 12-16 tahun. Murid yang hadir pada saat kuesioner dibagikan dan mengembalikannya berjumlah 1157 orang $(81,5 \%)$. Didapatkan data attack rate sebesar 446 (38,5\%) pada murid baik sedang sakit atau telah sembuh dari sakit dalam waktu 2 minggu sebelum kuesioner dibagikan. Murid dengan gejala kuning sebanyak 168 orang (37,7\%). Jumlah murid yang dirawat adalah 19 orang (4,3\%). Attack rate hepatitis akut per kelas tertera pada Tabel 1 . Terlihat attack rate tertinggi terdapat pada subyek dari kelas III. Hampir lima puluh persen subyek dari kelas III menderita hepatitis akut. Hasil pemeriksaan serologis subyek sakit tertera pada Tabel 2 .

Dua orang di antara subyek yang dirawat, tidak masuk sekolah pada saat dilakukan pengambilan darah. Dari 17 orang yang diambil darah, 1 sampel darah lisis sehingga tidak dapat diperiksa. Didapatkan IgM anti HAV positif pada 14 dari 16 sampel yang diperiksa.

Jumlah subyek sakit yang tidak dirawat 427 orang, dan 45 orang di antaranya diperiksa serologis IgM antiHAV. Tiga puluh delapan sampel $(84,4 \%)$ dari 45 sampel dengan hasil IgM antiHAV positif. Terdapat 1 sampel darah dengan hasil IgM antiHAV yang borderline, pasien ini dengan gejala ikterus sebelumnya. Bila sampel ini dianggap positif maka 39 dari 45 sampel positif $(86,7 \%)$. Gejala klinis yang timbul pada pasien dengan IgM antiHAV positif tertera pada Tabel 3. Gejala terbanyak adalah urin berwarna gelap, lemah, dan demam. Gejala ikterus didapatkan pada 36,5\% subyek.

Tabel 1. Attact rate hepatitis akut per kelas

\begin{tabular}{cccc}
\hline Kelas & Jumlah murid & Jumlah murid sakit & Presentase sakit \\
\hline I & 442 & 165 & 37.3 \\
II & 338 & 94 & 27,8 \\
III & 377 & 187 & 49,6 \\
Jumlah & 1157 & 446 & 38,5 \\
\hline
\end{tabular}


Sari Pediatri, Vol. 6, No. 4, Maret 2005

Tabel 2. Hasil pemeriksaan serologis subyek sakit

\begin{tabular}{lccccl}
\hline Subyek & $\begin{array}{c}\text { Jumlah } \\
\text { subyek }\end{array}$ & $\begin{array}{c}\text { Jumlah } \\
\text { darah yang } \\
\text { diambil }\end{array}$ & $\begin{array}{c}\text { Jumlah } \\
\text { darah yang } \\
\text { diperiksa }\end{array}$ & $\begin{array}{c}\text { IgM } \\
\text { Anti HAV } \\
(+)\end{array}$ & Keterangan \\
\hline Dirawat & 19 & 17 & 16 & $14(87,5 \%)$ & $\begin{array}{l}1 \text { sampel darah lisis } \\
\text { Tidak dirawat }\end{array}$ \\
427 & 45 & 45 & $38(84,4 \%)$ & $\begin{array}{l}\text { Masih terdapat 11 sampel } \\
\text { positif borderline dengan } \\
\text { riwayat ikterus }\end{array}$ \\
\hline
\end{tabular}

\begin{tabular}{lllll}
\hline Jumlah & 446 & 62 & 61 & $52(85,2 \%)$
\end{tabular}

Tabel 3. Gejala klinis 52 orang murid dengan IgM HAV (+)

\begin{tabular}{lll}
\hline Gejala klinis & Jumlah & $\%$ \\
\hline Urin gelap & 35 & 67,3 \\
Lemah & 30 & 57,7 \\
Demam & 26 & 50 \\
Muntah & 25 & 48 \\
Anoreksia & 25 & 48 \\
Nyeri perut & 24 & 46 \\
Kuning & 19 & 36,5 \\
Diare & 13 & 25 \\
Mialgia & 10 & 19,2 \\
\hline
\end{tabular}

Pada 711 orang subyek yang tidak sakit, 89 murid secara random diperiksa IgG dan IgM AntiHAV. Empat puluh enam orang $(51,6 \%)$ dengan IgG AntiHAV positif dan IGM anti HAV negatif, 2 orang mempunyai kadar IgM antiHAV positif dan IgG antiHAV positif.

\section{Diskusi}

Chitambar $\mathrm{dkk},{ }^{7}$ melaporkan kejadian luar biasa hepatitis akut di tempat penitipan anak di Pune, India. Tujuh dari 15 anak di tempat penitipan anak tersebut mengalami gejala klinis hepatitis dan terbukti karena HVA. Arce dkk, ${ }^{9}$ melaporkan kejadian luar biasa hepatitis A di tempat penitipan anak di Madrid pada 23 orang, 8 anak berusia 1-3 tahun (attack rate 8,7\%). Poonawagul $\mathrm{dkk},{ }^{10}$ melaporkan kejadian luar biasa hepatitis A sebesar 8\%. Sinlaparatsame dkk, ${ }^{6}$ melaporkan kejadian luar biasa di Thailand pada sekolah dengan jumlah murid 269 orang berusia 7-12 tahun. Terdapat 70 dari 89 subyek yang diperiksa serologis dengan anti HAV positif, 16 orang di antaranya dengan Ig $\mathrm{M}$ anti HAV positif. Pada penelitian di SMPN 259 ini dilaporkan attact rate sebesar 38,5\% dengan jumlah kasus 446 orang murid, $85,2 \%$ di antara subyek yang diperiksa terbukti IgM antiHAV positif. Dilihat dari jumlah subyek yang sakit, laporan ini jauh lebih besar dari yang pernah dilaporkan sebelumnya yang terjadi di sekolah atau tempat penitipan anak. Attack rate terbesar pada laporan ini pada murid kelas III pada anak berusia sekitar 15-16 tahun. Mengingat bahwa penularan HVA adalah fekal-oral, kemungkinan murid kelas III lebih banyak terpapar dengan sumber penularan di bandingkan dengan murid kelas I dan II.

Pada penelitian ini diketahui 19 (4,3\%) dari 446 subyek yang sakit memerlukan perawatan di rumah sakit. Tidak terdapat kasus meninggal dalam penelitian ini. A Richmond dkk, ${ }^{11}$ melaporkan kematian karena hepatitis A pada 3 orang pada kejadian luar biasa hepatitis A di Pennsylvania Barat akibat mengkonsumsi makanan yang terkontaminasi VHA di restoran Mexico. Menurut Richmond dkk ini adalah laporan kematian yang terbesar dari kejadian luar biasa hepatitis A. Di Shanghai dari 292.301 kasus yang dilaporkan antara Januari dan Maret 1988 pada suatu kejadian luar biasa hepatitis A di komunitas, terdapat 32 kematian $(0,01 \%) .{ }^{12}$ Tidak adanya kematian pada penelitian ini mungkin karena jumlah subyek yang sakit tidak besar.

IgM antiHAV dapat dideteksi 5-10 hari sebelum timbulnya gejala dan dapat bertahan sampai 6 bulan setelah infeksi. Terdapat 2 kasus dari 89 subyek yang tidak sakit yang diperiksa, dengan IgM antiHAV positif, IgG antiHAV positif. Hal ini menunjukkan bahwa pada kasus hepatitis A terdapat penderita yang tidak bergejala pada murid SMP. Empat puluh enam orang $(51,6 \%)$ dengan IgG antiHAV positif dan IGM anti HAV negatif menunjukkan bahwa subyek ini sudah pernah terinfeksi VHA sebelumnya dan telah memiliki kekebalan terhadap penyakit ini. Akbar dkk, ${ }^{13}$ melaporkan di Jakarta, Bandung, dan Sulawesi pada kelompok umur 
12-15 tahun pada tahun 1981, antiHAV total positif didapatkan berturut-turut Jakarta 12/17 (60\%), Bandung 9/12 (75\%), dan Sulawesi 12/20 (60\%) subyek dan meningkat pada kelompok 15-20 tahun berturut-turut menjadi 35/46 (76\%), 4/5 (80\%), 7/10 (70\%) subyek. Pada tahun 1994 pada kelompok 15-20 tahun dari 106 subyek didapatkan 12,3\% antiHAV total. Terlihat penurunan prevalens antiHAV total dibandingkan laporan sebelumnya. Akbar $\mathrm{dkk},{ }^{13}$ juga melaporkan penurunan seropositif antiHAV dengan makin tingginya status ekonomi. Dibandingkan dengan laporan Akbar, seropositif pada subyek yang tidak sakit pada penelitian ini $(51,6 \%)$ jauh lebih tinggi dari laporan tahun 1994, tetapi hampir sama dengan laporan 1981. Hal ini mungkin berhubungan dengan perubahan status ekonomi, higiene, dan sanitasi subyek setelah krisis ekonomi (tahun 1998).

\section{Ucapan terima kasih}

Ucapan terima kasih disampaikan pada tim Subdit Survailans Departemen Kesehatan Republik Indonesia, tim Dinas Kesehatan Propinsi DKI Jakarta, tim Suku Dinas Kesehatan Kotamadya Jakarta Timur, tim Puskesmas Cipayung, dan Pokja Hepatitis B yang turut membantu pelaksanaan penelitian ini.

\section{Daftar Pustaka}

1. Kemmer NM, Miskovsky EP. Hepatitis A. Infect Dis Clin North Am 2000;14: 605-15.

2. Liaw YF, Yang CY, Chu CM, Huang MJ. Appearance and persistence of hepatitis A IgM antibody in acute clinical hepatitis A observed in an outbreak. Infection 1986; 14:156-8.
3. Stapleton JT. Host immune response to hepatitis A virus. J Infect Dis 1995; 171(suppl1):S9-14.

4. Akbar N. The risk factors of hepatitis A,B,C and G in Jakarta, Indonesia-A population based study. Edisi pertama. Jakarta:BP FKUI;1997.

5. Boughton CR, Hawkes RA, Lehmann NI, Grohmann GS. Hepatitis A outbreak in a residential school. Aust N Z J Med 1980; 10:4-6, abstrak.

6. Sinlaparatsamee S, Nuniem J, Kankao J, Theamboonlers A, Chumdermpadetsuk S, Poovorawan Y . An outbreak of hepatitis A in school children at Nakhon Si Thammarat, southern Thailand. Southeast Asian J Trop Med Public Health 1995; 26:104-8.

7. Chitambar SD, Chadha MS, Yeolekar LR, Arankalle VA. Hepatitis A in day care centre. Indian J Pediatr 1996; 63:781-3.

8. Villar LM, da Costa MDCE, de Paula VS, Gaspar AMC.. Hepatitis A outbreak in a public school in Rio de Janeiro, Brazil. Mem Inst Oswaldo Cruz 2000; 97:301-5.

9. Arce AA, Rodero GI, Inigo MJ, Burgoa AM, Guevara AE.. Hepatitis A outbreak in a day care center and household transmission. An Pediatr 2004; 60:222-7.

10. Poonawagul U, Warintrawat S, Snitbhan R, Kitisriwarapoj S, Chaiyakun V, Foy HM. Outbreak of hepatitis A in a college traced to contaminated water reservoir in cafeteria. Southeast Asian J Trop Med Public Health 1995; 26:705-8.

11. Richmond, Josefson VD. Three die in US outbreak of hepatitis A. BMJ 2003; 327:1188.

12. Halliday ML, Kang LY, Zhou TK, Hu MD, Pan QC, Fu TY, Huang YS, Hu SL. An epidemic of hepatitis A attributable to the ingestion of raw clams in Shanghai, China. J Infect Dis 1991; 164:852-9.

13. Akbar N, Waspaji S, Sulaiman A, Noer HMS. Changing patterns of seromarker of hepatitis A infection in urban population in Jakarta. Maj Kes Masy Indones 1997; 25:467-70. 